\title{
A economia política da população: poder e demografia no pensamento econômico britânico do século XVII ${ }^{1}$
}

\author{
Carlos E. Suprinyak ${ }^{2}$
}

\begin{abstract}
Resumo
Em seus escritos sobre a "governamentalidade", Foucault argumenta que a filosofia política, durante o início do período moderno, perpetrou uma mudança gradual no objeto de exercício do poder, deixando de lado o território para concentrar-se sobre a população. Neste artigo, buscamos associar essa idéia com o pensamento econômico britânico do século XVII, em que noções de gerência populacional estão sempre presentes - primeiramente com autores do início do século como Mun e Misselden, evoluindo então ao longo das décadas seguintes em estreita relação com doutrinas como a "aritmética política" vislumbrada por Petty e culminando no uso extensivo por parte de Davenant das estatísticas demográficas de Gregory King. Além disso, tentamos expor a ligação entre temas populacionais e alguns conceitos-chave então utilizados, mostrando que esses temas não possuíam motivação meramente militar, mas sim derivavam de uma percepção do trabalho como força criativa, à qual podemos associar os rudimentos de uma teoria do valor-trabalho.
\end{abstract}

Palavras-chave: Mercantilismo; População; Século XVII; Teoria do trabalho como base no valor; Petty, William.

\begin{abstract}
The political economy of demographic management: power and population in XVII century British economic thought

In his lectures on governmentality, Foucault argued that Early Modern Period's political theorizing was characterized by a gradual change in the object of political power, from territories to populations. We try to link this idea to the development of seventeenth-century British economic thought, in which notions of population management are constantly present - beginning with early pamphleteers like Mun and Misselden, developing along the subsequent decades in a close relationship with doctrines such as the "political arithmetic" envisaged by Petty, and culminating in the extensive use made by Davenant of the demographic statistics compiled by Gregory King. Moreover, we try to expose the connection between demographic themes and some key concepts then adopted, in an effort to show that they were not mere subsidiaries to military concerns, but instead were a direct corollary to a widespread notion of labor as a creative force - arguably the rudimentary origins of a labor theory of value.
\end{abstract}

Key words: Mercantilism; Population; Seventeenth century; Labor theory of value; William Petty. JEL B110; N330; J180; I380; J680.

(1) Trabalho recebido em setembro de 2007 e aprovado em dezembro de 2007.

(2) Professor da Universidade Federal de Minas Gerais / Cedeplar, Belo Horizonte, MG, Brasil. E-mail: suprinyak@cedeplar.ufmg.br.

Economia e Sociedade, Campinas, v. 17, n. 3 (34), p. 383-402, dez. 2008. 
Carlos E. Suprinyak

$[\ldots]$ a mistake, that the greatness and glory of a Prince lyeth rather in the extent of his Territory, then in the number, art, and industry of his people, well united and governed. William Petty. A treatise of taxes and contributions.

'Tis not extent of Territory that makes a Country Powerful, but numbers of Men well employ'd, convenient Ports, a good Navy, and a Soil producing all sorts of Commodities. Charles Davenant. An essay upon the probable methods of making a people gainers in the balance of trade.

Ao discutir a evolução das formas de exercício do poder político, Foucault introduziu o conceito de governamentalidade visando descrever o modo específico de governo, nascido durante o período moderno, que caracteriza as instituições contemporâneas. Para ele, a queda da ordem feudal e subseqüente emergência dos modernos estados-nação ocasionaram a supressão gradual da noção tradicional de soberania, caracterizada por uma relação de transcendência entre o soberano e seus domínios. Dentro desse contexto tradicional, o principal propósito da ação política seria garantir posse e domínio sobre uma extensão territorial com a qual o soberano não possuía, necessariamente, vínculos estreitos. Pouca atenção era dispensada aos súditos, que eram considerados, de forma similar ao próprio território, como possessões do príncipe. Caso ao soberano fosse necessário tratar com seus súditos, ele o faria por meio de medidas repressivas e/ou manipulativas destinadas a garantir um equilíbrio interno de forças que mantivesse seus inimigos, domésticos ou externos, constantemente em xeque, preservando assim o controle sobre seus domínios políticos. No que se refere a suporte intelectual, Foucault aponta Maquiavel como o porta-voz por excelência desse modelo de soberania possessiva.

Em contraste com essa noção transcendente de soberania, Foucault argumenta que o período moderno teria testemunhado a emergência gradual de um conjunto diverso de idéias e conceitos que transferiram a arena privilegiada de exercício do poder político. Em vez da posse e domínio sobre uma extensão territorial, o principal objetivo político do soberano passa a ser a gerência adequada dos recursos materiais a seu dispor: as dotações naturais de seus domínios e, acima de tudo, sua população. Em oposição explícita ao modelo político de Maquiavel, um novo conjunto de obras começa a surgir, cuja principal preocupação é com a "arte de governar", e que tenta reconciliar o poder político com outros modos de exercício do poder encontrados na sociedade civil - o poder moral do homem sobre si próprio, o poder econômico do chefe do domicílio sobre seus dependentes.

Segundo o raciocínio de Foucault, o reconhecimento da população como uma entidade independente, dotada de seus movimentos, regularidades e lógica interna próprios, torna possível o surgimento por vez primeira de uma ciência do 
governo. Impulsionado por processos sociais ocorridos durante o início do período moderno, tais como intensa expansão demográfica e difusão das relações de mercado através do tecido social, o reconhecimento do fenômeno populacional teria permitido a superação de dois modelos inadequados para a ação política: o abrangente, transcendente e tradicional modelo da soberania, por um lado, e o excessivamente restritivo modelo patriarcal, por outro. O resultado dessa quebra fundamental foi o estabelecimento de uma associação orgânica entre o poder político e essa recém-descoberta dimensão social. A população - sua riqueza, seu bem-estar, seu desenvolvimento ordenado - seria a partir de então, vista como o objetivo político fundamental. Mais do que isso, seria, também vista como o principal meio para a consecução de tal objetivo, transformando-se no locus da ação política. Seria por meio de uma gerência adequada da população que os príncipes conseguiriam atingir seus objetivos de grandeza e prosperidade nacional.

Foucault associa o surgimento desse novo arcabouço político de governamentalidade com outros processos intelectuais paralelos. Em particular, enfatiza os vínculos estreitos existentes entre a noção de governo científico e outras inovações significativas ocorridas nos campos da economia e da estatística durante a segunda metade do século XVIII - período em que Foucault identifica a erupção da questão da governamentalidade. O propósito do presente artigo é mostrar que preocupações similares com a gerência da população já eram exibidas de forma abundante por toda a literatura econômica britânica do século XVII. Recuperando alguns dos tópicos mais freqüentemente debatidos durante esse período, pretendemos destacar a existência de um leitmotiv naquele contexto intelectual específico, relacionado com a população e sua organização adequada como formas de promover o poder e a riqueza nacionais.

\section{Arte e natureza}

Temas populacionais na literatura econômica britânica do século XVII podem ser relacionados a uma preocupação pública central: emprego. Repetidas exortações à ocupação produtiva do maior número possível de homens podem ser encontradas espalhadas por todo esse conjunto de obras. As razões por trás de propostas dessa natureza podem assumir basicamente duas formas: primeiramente, o emprego e seu corolário imediato, o trabalho humano, são vistos como uma forma de criação de riqueza - freqüentemente, como a forma mais desejável de criação de riqueza; em segundo lugar, preocupações com a ordem social induziram alguns autores do período a enfatizar a desejabilidade do emprego produtivo dos pobres, não apenas como forma de integrar socialmente tais contingentes demográficos deslocados das atividades econômicas tradicionais, mas também visando evitar agitações sociais e, ao mesmo tempo, disciplinar a força de trabalho. Este segundo ponto será discutido em maior detalhe mais adiante. Pelo 
momento, nos deteremos na questão do emprego considerada a partir de uma perspectiva estritamente econômica.

As origens dessa noção de trabalho como fonte de valor e riqueza podem ser associadas a uma distinção conceitual bastante popular desde o início do século, aquela entre riquezas naturais e artificiais. Tomados de empréstimo a Aristóteles, esses conceitos foram claramente apresentados por Gerard de Malynes já em um panfleto de 1601, A treatise of the canker of England's commonwealth. A distinção proposta entre as duas formas de riqueza é, de fato, muito simples: enquanto as riquezas naturais são compostas por tudo aquilo provido pela natureza, como solos férteis e recursos minerais, riquezas artificiais são aquelas que, embora em última análise também oriundas da natureza, recebem sua forma e uso definitivos por virtude da indústria humana (Malynes, 1601, p. 5).

De forma compatível com sua visão tipicamente escolástica em tópicos semelhantes, Malynes acreditava na necessidade de uma espécie de equilíbrio entre riquezas naturais e artificiais, uma vez que as últimas procedem das primeiras. Malynes vislumbrava as riquezas artificiais como limitadas pelo estoque disponível de riquezas naturais, não depositando, dessa forma, grande confiança nos poderes criativos do trabalho humano. Tal perspectiva seria em breve desafiada por Thomas Mun, autor que, em oposição a Malynes, encontravase plenamente disposto a conceber o trabalho como meio de ampliar significativamente a riqueza nacional.

Mercador membro da Companhia das Índias Orientais, Mun igualmente adotou a distinção entre riquezas naturais e artificiais em sua panfletária defesa das atividades comerciais da companhia, A discourse of trade from England unto the East Indies (1621). Assim como Malynes, Mun exalta a Inglaterra por sua farta provisão de riquezas naturais, "both in the Sea for Fish, and on the Land for Wooll, Cattle, Corne, Lead, Tin, Iron, and many other things for Food, Rayment \& Munition" (Mun, 1621, p. 48-49). Tais dotações naturais garantiam a autonomia inglesa em relação a outras nações no tocante à subsistência doméstica. Entretanto, se uma nação pretende crescer e enriquecer, não é com as riquezas naturais que deve se ocupar. A chave da prosperidade encontra-se nas riquezas artificiais:

But to live well, to flourish and grow rich, wee must find meanes by Trade, to vent our superfluities; therewith to furnish and adorne us with the Treasure and those necessarie wares, which forreine Nations do afford: and here industry must begin to play his part, not onely to increase and guide the Trades abroad; but also to mantaine and multiply the Arts at home: for when either of these faile, or are not effected with such skill as ther mysterie shal require, the Common-wealth doth abate and grows poore (Mun, 1621, p. 49).

Idéias como essas, formuladas de forma incipiente no discurso, receberiam tratamento mais detalhado no magnum opus de Mun, England's 
treasure by forraign trade (1664). Nesse tratado, publicado postumamente, cuja redação provavelmente ocorrera durante a turbulenta década de 1620, Mun aparenta estar fascinado com o conceito de "arts" - em especial com o potencial destas para criar riqueza em quantidade muito superior àquela originalmente provida pela natureza. Tais "arts" devem ser entendidas como habilidades manuais em geral, como a capacidade do homem para transformar os produtos da natureza por meio de seu trabalho. Para Mun, as "arts" são não apenas uma forma legítima de aquisição de riqueza por parte de uma nação; elas são até mesmo mais importantes do que as próprias riquezas naturais, visto que nelas reside a capacidade de envolver um maior número de pessoas:

[I]n all things we must endeavour to make the most we can of our own, whether it be Natural or Artificial; And forasmuch as the people which live by the Arts are far more in number than they who are masters of the fruits, we ought the more carefully to maintain those endeavours of the multitude, in whom doth consist the greatest strength and riches of both King and Kingdom: for where the people are many, and the arts good, there the traffique must be great, and the Countrey rich (Mun, 1664, p. 12, grifo adicionado).

Logo em seguida, após discutir a importância das manufaturas para a riqueza nacional da Itália, Mun descreve de forma ainda mais enfática o potencial produtivo da indústria e da arte humanas:

[W] hat need we fetch the example so far, when we know that our own natural wares doe not yield us so much profit as our industry? For Iron oar in the Mines is of no great worth, when it is compared with the employment and advantage it yields being digged, tried, transported, bought, sold, cast into Ordnance, Muskets, and many other instruments of war for offence and defence, wrought into Anchors, bolts, spikes, nayles and the like, for the use of Ships, Houses, Carts, Coaches, Ploughs, and other instruments for Tillage. Compare our Fleece-wools with our Cloth, which requires shearing, washing, carding, spinning, Weaving, fulling, dying, dressing and other trimmings, and we shall find these Arts more profitable than the natural wealth... (Mun, 1664, p. 13).

Em contraste com as idéias de Malynes acerca dos limites impostos sobre as riquezas artificiais pela disponibilidade de riquezas naturais, Mun parece conceber a capacidade da indústria humana em criar riquezas artificiais como quase ilimitada. Preocupado como estava com o aumento da riqueza da Inglaterra, lamentava a morosidade induzida sobre a população inglesa pela benevolência da natureza (tópico a ser discutido em detalhes mais adiante), pregando: "[...] our wealth might be a rare discourse for all Christendome to admire and fear, if we would but add Art to Nature, our labour to our natural means" (1664, p. 73). Arte e natureza, a natureza transformada pela arte humana abrindo caminho rumo à grandeza nacional. 
Obviamente, natureza e arte, enquanto fontes potenciais de riqueza, encontram-se estreitamente vinculadas à utilização econômica de dois fatores produtivos fundamentais: terra e trabalho. Não obstante, por nunca ter formulado claramente o problema teórico do valor, Mun satisfez-se ao simplesmente postular a existência de uma relação entre natureza, arte e riqueza, sem se preocupar em estabelecer a forma exata em que natureza e arte combinavam-se e trabalhavam conjuntamente para criar tal riqueza. Essa tarefa viria a ser empreendida aproximadamente quarenta anos mais tarde por outro pioneiro economista britânico, William Petty.

Petty, autor de grande relevância para nossos propósitos, cujas idéias teremos oportunidade de discutir detidamente mais adiante, foi muito aclamado por gerações posteriores de economistas por ter desenvolvido uma formulação precursora da teoria do valor-trabalho - feito que lhe garantiu um posto como mercantilista favorito de Marx. Nesse sentido, ao se debater com a explicação teórica dos preços relativos entre a prata e os cereais em seu $A$ treatise of taxes and contributions (1662), Petty assim resolveu o problema:

And forasmuch as possible there may be more Art and Hazzard in working about the Silver, then about the Corn, yet all comes to the same pass; for let a hundred men work ten years upon Corn, and the same number of men, the same time, upon Silver; I say, that the neat proceed of the Silver is the price of the whole neat proceed of the Corn, and like parts of the one, the price of like parts of the other (Petty, 1662, p. 43).

Nessa formulação, Petty enfatiza a importância fundamental do trabalho na criação do valor, temporariamente deixando de lado o papel desempenhado pela terra nesse processo. Entretanto, ele imediatamente recua e restabelece ambos os fatores em um mesmo nível:

Our Silver and Gold we call by severall names, as in England by pounds, shillings, and pence, all which may be called and understood by either of the three. But that which I would say upon this matter is, that all things ought to be valued by two natural Denominations, which is Land and Labour; that is, we ought to say, a Ship or garment is worth such a measure of Land, with such another measure of Labour; forasmuch as both Ships and Garments were the creatures of Lands and mens Labours thereupon; This being true, we should be glad to finde out a natural Par between Land and Labour, so as we might express the value by either of them alone as well or better then by both, and reduce pence into pounds (1662, p. 44, grifo adicionado).

Dessa forma, ao conferir um significado mais concreto às noções um tanto esotéricas de natureza e arte, Petty pôde transformar as idéias intuitivas de Mun acerca da possibilidade do progresso material por meio da adição de arte à natureza em uma teoria bastante explícita de determinação do valor. Além disso, após minimizar a relevância do caráter específico de cada arte (conforme se nota 
na primeira transcrição acima), Petty estabeleceu uma noção mais homogênea de trabalho e indústria que lhe possibilitou criar um vínculo direto entre trabalho e questões populacionais:

Here we are to remember in consequence of our opinion [That Labour is the Father and active principle of Wealth, as Lands are the Mother], that the State by killing, mutilating, or imprisoning their members, do withall punish themselves; wherefore such punishments ought (as much as possible) to be avoided and commuted for pecuniary mulcts, which will encrease labour and publick wealth (1662, p. 71).

Assim, o reconhecimento do trabalho como fonte de riqueza traduz-se em uma receita para a boa administração dos assuntos públicos. Obviamente, o vínculo crucial aqui é a idéia de emprego. Dado que a escolha entre as diversas artes é mais ou menos indiferente, já que todas elas geram riqueza por meio da capacidade do trabalho em criar valor, uma nação que pretende melhorar suas próprias condições materiais deve se esforçar para obter domesticamente a maior quantidade possível de trabalho. Aumentar a quantidade de trabalho significa, neste contexto, empregar a população. Preocupações com habilidades manuais e engenhosidade, típicas de escritores do início do século como Malynes e Mun, foram assim substituídas por um objetivo muito mais pragmático: dar emprego ao maior número possível de pessoas.

As idéias de Petty acerca do trabalho como fonte de valor foram subseqüentemente adotadas e desenvolvidas de forma ainda mais radical por uma série de autores econômicos britânicos. Charles Davenant, outro autor seminal dentro de nossa discussão, em seu An essay upon the probable methods of making a people gainers in the balance of trade (1699), estabeleceu de forma categórica a importância da população e de seu trabalho para o esplendor de uma nação:

The People being the first Matter of Power and Wealth, by whose labour and Industry a Nation must be Gainers in the Balance, their Increase or Decrease must be carefully observ'd by any Government that designs to thrive; that is, their Increase must be promoted by good Conduct and wholesome Laws, and if they have been Decreas'd by War, or any other Accident, the Breach is to be made up as soon as possible, for it is a Maim in the Body Politick affecting all its Parts (Davenant, 1699, p. 226).

É responsabilidade do Estado garantir uma contínua e adequada expansão demográfica, sendo essa a forma mais eficaz para incrementar a riqueza nacional. De forma ainda mais enfática que Petty, Davenant negligenciava diferenças qualitativas entre as manifestações concretas do trabalho, concentrando-se, em vez disso, sobre os números mobilizados:

The Bodies of Men are without doubt the most valuable Treasure of a Country; and in their Sphere, the ordinary People are as serviceable to the Common-wealth as the rich, if they are employed in honest Labour and useful Arts: And such being 
Carlos E. Suprinyak

more in Number, do more contribute to increase the Nation's Wealth, than the higher Rank (1699, p. 238).

Nos escritos de Josiah Child, um dos autores mais populares e respeitados do período, também podemos encontrar proposições explícitas a respeito da superioridade do trabalho sobre a terra na promoção da riqueza material. Nesse sentido, afirmava ele em A new discourse of trade (1693): "[...] most Nations in the civilized Parts of the World, are more or less Rich or Poor proportionably to the Paucity or Plenty of their People, and not to the Sterility or Fruitfulness of their Lands" (Child, 1693, p. 105). Nicholas Barbon, como último exemplo, também professou raciocínio similar: "[...] every man that works, is paid for his time; and the more there are employ'd in a Nation, the richer the Nation grows" (Barbon, 1696, p. 178). Assim, parece provável que a noção de trabalho como a forma mais poderosa de criação de valor, assim como a crença estritamente correlata na possibilidade de incremento da riqueza nacional por meio do emprego da população induzido pelo Estado, eram idéias bastante disseminadas na Inglaterra de fins do século XVII.

\section{A questão dos pobres}

Conforme mencionado acima, o desejo de ver a população do reino empregada, expresso por autores econômicos do século XVII, pode ser compreendido em conexão com duas preocupações centrais. A primeira delas, relacionada com uma receita para a prosperidade nacional baseada no trabalho do povo, foi exposta na seção precedente. Voltamos agora nossa atenção para a segunda dessas preocupações, em que o emprego é visto como uma forma de alcançar estabilidade social.

Esse vínculo entre emprego e estabilidade social pode ser, ele próprio, decomposto em dois aspectos diversos, embora ambos estejam relacionados a um problema central: a pobreza. Em uma época marcada por intensas rupturas sociais ocasionadas por mudanças profundas na estrutura econômica da Europa, tratar da crescente massa de pobres e desempregados que vagavam pelo campo e pelas cidades constituía uma tarefa pública de máxima prioridade e urgência. Os autores econômicos de então demonstraram aguda sensibilidade para tais questões, oferecendo suas diversas perspectivas a respeito. Especificamente, acreditavam ser preferível dar trabalho aos pobres do que fazê-los depender de caridade pública ou privada. Tal preferência advinha de várias razões: empregar os pobres significava aumentar a riqueza da nação por meio de uma adição ao fluxo de trabalho ofertado - em conseqüência direta dos argumentos apresentados na seção anterior; além disso, o trabalho promoveria uma integração mais coesa dos pobres no tecido social - em vez de serem mendigos vivendo à custa da benevolência de terceiros, eles estariam trabalhando para obter seu sustento material; finalmente, inibindo a 
vadiagem prevenia-se, ao mesmo tempo, convulsões sociais, já que trabalhadores estariam menos propensos a se reunir em locais públicos e provocar tumultos. Como resultado dessa atitude de desaprovação com relação à caridade e aos indivíduos dela dependentes, os autores britânicos eram em regra críticos severos das Poor laws da nação - seja do próprio princípio que as orientava, seja das formas específicas em que eram colocadas em prática.

Por outro lado, dar emprego aos pobres era uma diretriz de política pública defendida também em termos morais. Pessoas que não trabalham tornamse preguiçosas, argumentava-se. Era necessário manter os pobres trabalhando de forma a inculcar-lhes um espírito de indústria e laboriosidade que seria necessário quando a prosperidade nacional finalmente tornasse possível sua eficiente ocupação produtiva. Investidas morais dessa natureza contra o fenômeno do desemprego podem ser encontradas em profusão já nos escritos do início do século XVII. Para Malynes, um dos benefícios advindos do afluxo de metais preciosos seria que "artificers and workmen shall be set on worke, to avoid idlenesse which is the root of all mischief" (1601, p. 17). Edward Misselden, seu oponente intelectual, guardava opinião similar: "He that's Idle, is fit for any Evill" (Misselden, 1623, p. 132). Mais do que isso, Misselden constantemente demonstrava preocupação com a ocupação produtiva dos pobres, mesmo quando não expunha claramente qual o curso de ação a ser tomado. Ao defender os negócios da Companhia das Índias Orientais, ele os definiu da seguinte forma: “An excellent meanes to advance our Navigation, and to employ our Multitudes of poore" (1623, p. 35).

Dar trabalho aos pobres parece ter sido ordinariamente percebido desde o início do século XVII como um resultado desejável da atividade econômica. Mun, falando em favor da Companhia das Índias Orientais, apelava constantemente ao número de pobres que conseguiam encontrar emprego graças às atividades da companhia (1601, p. 29-31). Em England's treasure, Mun chegou a argumentar a favor de gastos suntuosos por parte dos ricos como forma de empregar os pobres um tópico muito controverso no período, conforme veremos em breve. Também ao favorecer a importação de matérias-primas para manufatura doméstica e posterior reexportação, seu raciocínio era semelhante:

[I]f in our raiment we will be prodigal, yet let this be done with our own materials and manufactures, as Cloth, Lace, Imbroderies, Cutworks and the like, where the excess of the rich may be the employment of the poor (Mun, 1664, p. 9).

It were policie and profit for the State to suffer manufactures made of foreign Materials to be exported custome-free, as Velvets and all other wrought Silks, Fustians, thrown Silks and the like, it would employ very many poor people [...]. I will here remember a notable increase in our manufacture of winding and twisting only of forraign raw Silk, which within 35 years to my knowledge did not employ more than 300 people in the City and suburbs of London, where at this present time 
Carlos E. Suprinyak

it doth set on work above fourteen thousand souls, as upon diligent enquiry hath been credibly reported unto His Majesties Comissioners for Trade (p. 11).

Esse mesmo tema foi mais tarde abordado por Petty, que foi mais adiante e transformou-o em domínio sujeito a administração pública sistemática. O poder produtivo dos pobres, dizia ele, deve ser utilizado para incrementar a produção econômica nacional. É interessante notar o caráter marcadamente utilitarista da abordagem de Petty para o tema. Sua preocupação principal não é com o fardo que os pobres podem representar para a nação, pois acreditava que o excedente econômico era suficiente para mantê-los. Para Petty, o problema era que, ao manter os pobres meramente por meio de caridade, a nação estava desperdiçando sua força de trabalho e sua capacidade de criação de riqueza. O seguinte trecho, embora longo, ilustra com muita clareza as várias nuances do programa público de auxílio aos pobres proposto por Petty:

When all helpless and impotent Persons were thus provided for, and the lazy and thievish restrained and punished by the Minister of Justice, it follows now, that we finde out certain constant Employments for all other indigent people, who labouring according to the Rules upon them, may require a sufficiency of food and raiment. [...] But what shall these Employments be? I answer, [...] making all High-wayes so broad, firm, and eaven, as whereby the charge and tedium of travelling and Carriages may be greatly lessened. The cutting and scowring of Rivers into Navigable; the planting of useful Trees for timber, delight, and fruit in convenient places. The making of Bridges and Cawseys. The working in Mines, Quarries, and Colleries. The Manufactures of Iron, etc. [...] In the next place it will be asked, who shall pay these men? I answer, every body; for if there be 1000 men in a Territory, and if 100 of these can raise necessary food and raiment for the whole 1000. If 200 more make as much commodities, as other Nations will give either their commodities or money for, and if 400 more be employed in the ornaments, pleasure, and magnificence of the whole; if there be 200 Governours, Divines, Lawyers, Physicians, Merchants, and Retailers, making in all 900 the question is, since there is food enough for this supernumerary 100 also, how they should come by it? whether by begging, or by stealing; or whether they shall suffer themselves to starve, finding no fruit of their begging, or being taken in their stealing to put to death another way? Or whether they shall be given away to another Nation that will take them? I think 'tis plain, they ought neither to be starved, nor hanged, nor given away; now if they beg, they may pine for hunger to day, and be gorged and glutted to morrow, which will occasion Diseases and evil habits, the same may be said of stealing; moreover, perhaps they may get either by begging or stealing more than will suffice them, which will for ever after indispose them to labour, even upon the greatest occasion which may suddenly and unexpectedly happen. For all these Reasons, it will be certainly the safer way to afford them the superfluity which would otherwise be lost and wasted, or wantonly spent (Petty, 1662, p. 29-30).

$\mathrm{Na}$ transcrição acima, podemos também entrever o conteúdo moral da abordagem de Petty para o problema dos pobres, quando o autor expressa seu 
receio de que a falta de uma rotina de trabalho faria com que os homens sofressem de "Diseases and evil habits", ou de que a mendicância os deixaria indispostos para o trabalho. Petty recorreria mais uma vez às virtudes disciplinadoras do trabalho logo a seguir, nesta muito citada, e ainda assim memorável, passagem:

Now as to the work of these supernumeraries, let it be without expence of Foreign Commodities, and then 'tis no matter if it be employed to build a useless Pyramid upon Salisbury Plain, bring the Stones at Stonehenge to Tower Hill, or the like; or at worst this would keep their minds to discipline and obedience, and their bodies to a patience of more profitable labours when need shall require it (1662, p. 30).

Uma combinação similar entre utilitarismo e disciplina moral pode ser encontrada nos escritos de Child acerca do tema. Em A new discourse of trade, o autor dedica um capítulo inteiro ao estudo das políticas de caridade e emprego dos pobres. Ao introduzir o assunto, sua abordagem particular já vem à tona: “[...] our Poor in England, have always been in a most sad and wretched condition [...], Uncomfortable to themselves, and Unprofitable to the Kingdom" (1693, p. 57, grifo adicionado). Child demonstra preocupação com as crianças que crescem em meio à pobreza, não apenas devido à sua saúde precária, mas também pelo que define como "idle habits contracted in their Youth", que os deixariam indispostos para o trabalho. Após expor suas preocupações, conclui: “[...] if all our impotent Poor were provided for, and those of both Sexes and all Ages that can do Work of any kind, employed, it would redound some Hundreds of Thousands of Pounds per annum to the publick Advantage" (p. 57).

Child não é radicalmente contrário à caridade privada, porém nela não confia como forma eficiente para tratar o problema da pobreza. Nesse sentido, pôde afirmar confiantemente: "He that gives to any in Want does well; but he that gives to Employ and Educate the Poor, so as to render them useful to the Kingdom, in my judgment does better" (p. 58). De forma consonante, Child condenava as Poor laws como um sistema inadequado de assistência aos necessitados. Suas principais críticas recaíam sobre o sistema paroquial, que induzia cada paróquia, individualmente, a repelir mendigos e desocupados em vez de tentar dar-lhes trabalho - o que deveria ser o objetivo principal de qualquer sistema de auxílio aos pobres. Manifestando otimismo quanto às possibilidades de empregar produtivamente os pobres por meio de um esquema apropriado, ousou afirmar: "[...] the resort of Poor to a City or Nation well managed, is in effect, the conflux of Riches to that City or Nation" (p. 60).

Outro crítico mordaz das leis assistenciais britânicas de então foi Charles Davenant, que propôs a organização de um novo sistema de auxílio na forma de um empreendimento financiando por meio da emissão de quotas $(1699$, p. 240247). Davenant acreditava que o auto-interesse dos investidores seria um guia mais eficiente para alcançar uma solução satisfatória para problemas relacionados 
Carlos E. Suprinyak

à pobreza. Sua perspectiva mais ampla a respeito do tema da gerência populacional será objeto de escrutínio mais detalhado adiante, não cabendo dela nos ocuparmos aqui. Pelo momento, basta dizer que também Davenant considerava a vinculação das massas menos favorecidas a rotinas de trabalho como um tema central de política pública.

\section{Frugalidade e laboriosidade}

Até o momento, as prescrições morais que vimos defendidas pelos autores econômicos britânicos do século XVII eram de natureza bastante específica: concebiam o trabalho como forma eficaz de disciplinar as massas pobres para uma vida de trabalho duro. Não obstante, no que concerne a questões morais, esses autores tinham muito mais a dizer. Em estreita ligação com seu objetivo principal (i.e., aumentar a riqueza nacional), podemos dizer que defendiam dois valores morais fundamentais: de um lado a frugalidade, ou aversão ao consumo supérfluo e conspícuo; de outro, a laboriosidade, ou aversão ao ócio. Em contraste com o que era proposto em relação aos pobres, quando era implicitamente aceito que o emprego, por si só, conduziria quase automaticamente à retidão moral, no que tange à população em geral, o problema mostrava-se mais complexo. Frugalidade e laboriosidade, dizia-se, são hábitos difíceis de adquirir; mais ainda, acreditava-se comumente que esses eram hábitos com os quais o povo britânico, em especial, não contava. Inculcar tais valores na massa da população tornou-se, assim, um passo crucial a ser trilhado na estrada para a prosperidade nacional. Certamente não é coincidência que uma doutrina moral como esta tenha ganho terreno durante o século da Revolução Puritana.

Neste tópico particular, o exemplo oferecido pelos holandeses exerceu influência massiva. Aqui, mais uma vez, a distinção conceitual entre natureza e arte torna-se relevante. Como poderia uma nação tão pouco abençoada pela natureza como os Países Baixos transformar-se em tal ícone de grandeza e prosperidade? A resposta era simples: o que os holandeses não obtinham da natureza, eles compensavam com extrema diligência em seus assuntos econômicos. O sucesso holandês era a prova definitiva de que a arte era, de fato, um instrumento muito mais poderoso de criação de riqueza do que a natureza. Alguns chegavam até a sugerir que era precisamente a impossibilidade de recorrer aos presentes da natureza que fizera dos holandeses um povo tão notavelmente laborioso. Esta era a opinião de Mun, por exemplo:

As plenty and power doe make a nation vicious and improvident, so penury and want doe make a people wise and industrious: so concerning the last of these I might instance divers Commonwealth of Christendom, who having little or nothing in their own Territories, do notwithstanding purchase great wealth and strength by their industrious commerce with strangers, amongst which the united Provinces of the Low Countreys are now of greates note and fame (Mun, 1664, p. 73). 
Obviamente, o apelo à frugalidade encaixava-se de forma perfeita dentro do arcabouço analítico da doutrina do balanço comercial favorável, sendo assim enfaticamente endossado por autores do início do século XVII. Tão inclinados a contradizer um ao outro, Malynes e Misselden estavam de acordo nesse ponto. $\mathrm{O}$ primeiro condenava seus compatriotas por zombarem dos nativos das Índias Ocidentais, que trocavam metais preciosos por brinquedos tolos, enquanto cometiam o mesmo equívoco em seus negócios com as Índias Orientais, onde as úteis mercadorias britânicas eram trocadas por produtos supérfluos (1601, p. 7476). Ao passo que Misselden, ao discutir as causas de uma crise de liquidez na Inglaterra em seu Free trade or the meanes to make trade flourish (1622), apontou como primeira "causa mediata" o consumo de mercadorias estrangeiras supérfluas por "homens que vivem acima de seu chamado" e "promiscuamente adentram os estratos uns dos outros" (1622, p. 30-31).

Como vimos acima, Mun estava disposto a aceitar a prodigalidade dos ricos desde que esta se traduzisse em emprego para os pobres. Entretanto, a conclusão de seu argumento demonstra claramente como a noção de prodigalidade como vício moral encontrava-se profundamente arraigada à época:

[I]f in our raiment we will be prodigal, yet let this be done [...] where the excess of the rich may be the employment of the poor, whose labours notwithstanding of this kind, would be more profitable for the Commonwealth, if they were done to the use of strangers (Mun, 1664, p. 9, grifo adicionado).

Já ao final do século, John Locke ainda levaria a doutrina do balanço comercial favorável ao pé da letra, recorrendo à popular analogia entre o governo de um reino e o governo de uma família para concluir: tudo aquilo ganho por meio da "indústria, frugalidade e boa ordem" de um pai seria rapidamente dissipado pelas maneiras pródigas e negligentes de um filho que não pudesse "jantar sem Champane ou Burgundy, nem dormir se não em uma cama de damasco" (Locke, 1691, p. 67-68). Explorando sua principal linha de raciocínio nesse tratado, Locke argumentava ser inútil reduzir as taxas de juros por meios legais, pois a taxa "natural" determinada pelo mercado acabaria sendo estabelecida por outros caminhos. Quando essa taxa natural estivesse excessivamente elevada, a consequiência imediata seria decadência comercial, situação para a qual Locke vislumbrava a seguinte solução: "There is no way to recover from this, but by a general Frugality and Industry" (p. 60).

Atestando a ampla difusão da confiança nesses valores morais ainda ao final do século, concluímos esta seção recorrendo às palavras de Child, que embora adotasse uma perspectiva contrária à de Locke, ainda assim argumentava sobre as mesmas bases: "[...] Luxury and Prodigality are as well prejudicial to Kingdoms as to private Families; [...] but [...] nothing hath or will incline this or 
Carlos E. Suprinyak

any other Nation more to Thriftiness and good Husbandry, then abatement of Interest" (1693, p. 3).

\section{Balanço de rendimentos}

Conforme mencionado acima, os ideais morais de frugalidade e laboriosidade conformavam-se bem à doutrina do balanço comercial favorável. A frugalidade constituía uma forma eficaz de restringir importações, ao passo que a laboriosidade poderia converter-se em acréscimo nas exportações. Não obstante, mesmo ao fim do século XVII, quando a versão "ingênua" dessa doutrina já não era mais amplamente aceita, autores econômicos britânicos continuavam voltando suas atenções para questões populacionais na tentativa de compreender como uma nação poderia enriquecer e prosperar. À medida que o século avançava, a tradicional ânsia por um excedente de exportações foi sendo gradualmente substituída por uma preocupação levemente distinta, relacionada com um excedente de trabalho exportado.

A idéia de uma doutrina do balanço de rendimentos internacionalmente pagos foi desenvolvida originalmente por E. A. J. Johnson (1937, p. 301-315), e assim não será explorada aqui em detalhe ${ }^{3}$. Precisamos nos ocupar dela apenas na medida em que representa ainda outra maneira pela qual temas populacionais penetraram a literatura econômica do período. A forma definitiva dessa doutrina pode ser encontrada nos escritos de James Steuart, já na segunda metade do século XVIII. Steuart concebia o ganho obtido no comércio internacional como o excedente verificado entre a quantidade de trabalho exportado por uma nação e a quantidade de trabalho por ela importado de outras nações. Exportar "matéria", ou recursos naturais, constituiria perda para a nação, ao passo que importá-la representaria ganho. Assim, o balanço líquido de trabalho negociado deveria ser coberto por fluxos compensatórios de "matéria".

Argumentando de forma similar à que vínhamos fazendo até o momento, Johnson propõe que a noção de uma doutrina do balanço de trabalho favorável origina-se do reconhecimento da distinção entre riquezas naturais e artificiais. Uma vez reconhecido o trabalho como fonte imediata de valor, insinua-se logicamente a conclusão de que exportar bens manufaturados significa recompensar o trabalho doméstico às custas do exterior. Tal idéia encontrava-se já incorporada em propostas para regulamentação do comércio internacional formuladas ao longo do século, que defendiam restrições sobre a importação de bens manufaturados e estímulo à importação de matérias-primas, assim como medidas opostas mediante as exportações. Johnson assim resume a lógica que

(3) Mais recentemente, o conceito de uma teoria do balanço de rendimentos internacionalmente pagos foi atualizado por Magnusson (1994, p. 167). 
permeava a doutrina: "The goal of a wise nation ought to be to do without the produce of the labour or ingenuity of other nations, but without forcing those other nations to do without ones own" (p. 305).

Para nossos propósitos, o importante é notar que o reconhecimento do trabalho como principal, se não única, fonte de ganho no comércio com outras nações fornece ainda mais uma justificativa para estrito controle estatal sobre as atividades econômicas dos súditos. Veremos, agora, até que ponto os autores econômicos britânicos do século XVII estavam dispostos a ir em defesa da gerência populacional.

\section{A economia demográfica de Petty e Davenant}

Em meio a uma literatura constantemente pontuada por temas populacionais, dois autores merecem tratamento mais atento por terem sistematicamente proposto medidas para gerência demográfica por parte do Estado: William Petty e Charles Davenant. Demandas por uma população vasta e crescente já eram bastante comuns desde, pelo menos, a época de Mun. O que distingue Petty e Davenant da massa de autores que acreditavam no potencial do povo para criação de riqueza é sua disposição em conferir ao Estado a tarefa de garantir uma população não apenas vasta, mas também organizada de forma economicamente adequada.

As propostas de intervenção pública formuladas por esses autores eram baseadas em informações estatísticas, disponíveis com regularidade crescente durante a segunda metade do século XVII. Conforme vimos na Introdução, avanços no campo da estatística foram identificados por Foucault como um dos processos que concorreram para tornar possível a emergência da "ciência do governo" que tinha a população como seu objeto. Petty é largamente reconhecido como o autoproclamado pai da "Aritmética Política", método "até então não muito usual" que ele assim caracterizava:

[I]nstead of using only comparative and superlative Words and intellectual Arguments, I have taken the course to express my self in terms of Number, Weight, or Measure; to use only Arguments of Sense, and to consider only such Causes, as have visible Foundations in Nature; leaving those that depend upon the mutable Minds, Opinions, Appetites, and Passions of particular Men, to the Consideration of others (Petty, 1690, p. 239).

Trabalhando com estatísticas compiladas por ele próprio, bem como outras disponíveis de forma esparsa por toda a Europa, Petty demonstrava verdadeira fascinação com a quantificação de informações sociais e com a solidez que seu uso aparentemente conferia a qualquer argumento político. A esse respeito, Davenant declarava-se abertamente um discípulo de Petty, possuindo uma significativa vantagem sobre seu mestre: teve acesso às pesquisas de 
estatística social realizadas por Gregory King na última década do século, uma fonte extremamente rica de informações sobre a qual erigiu as bases de sua abordagem teórica. Davenant mostrava-se ainda mais fascinado do que Petty com a idéia de administrar cientificamente a população, que era vista por ele como um fenômeno social autônomo dotado de lógica interna própria.

Já no início de $A$ treatise of taxes and contributions, Petty deixa clara sua preocupação com uma distribuição adequada dos súditos do reino entre as diversas ocupações. O segundo capítulo do panfleto é quase inteiramente dedicado a propostas para racionalização e aprimoramento de setores inteiros no desempenho de suas tarefas. À guisa de exemplo, Petty argumenta que o número de paróquias na Inglaterra poderia ser cortado pela metade, com reduções concomitantes no número de autoridades eclesiásticas tais como bispos e deões, se apenas cada ministro fosse mais diligente e pregasse para um número maior de pessoas, espalhadas por mais ampla extensão territorial (1962, p. 24-25). Petty também acreditava que um sistema legal racionalizado reduziria drasticamente o número de profissionais requeridos na área, assim como o número de estudantes de Direito nas universidades (p. 25-26). Sua proposta para o sistema de saúde merece ser transcrita por ilustrar claramente o pragmatismo e escrutínio detalhado de Petty:

As for Physicians, it is not hard by the help of the observations which have been lately made upon the Bills of Mortality, to know how many are sick in London by the number of them that dye, and by the proportions of the City to finde out the same of the Countrey; and by both, by the advice of the learned Colledge of that Faculty to calculate how many Physicians were requisite for the whole Nation; and consequently, how many Students in that art to permit and encourage; and lastly, having calculated these numbers, to adoptate a proportion of Chyrurgeons, Apothecaries, and Nurses to them, and so by the whole to cut off and extinguish that infinite swarm of vain pretenders unto, and abusers of that God-like Faculty, which of all Secular Employments our Saviour himself after he began to preach engaged himself upon (Petty, 1662, p. 27).

Um dos argumentos favoritos de Petty em prol de uma vasta população era a suposta existência de algo como rendimentos crescentes de escala na administração pública: um número grande de pessoas pode ser tão bem governado quanto um número pequeno pelo mesmo aparato estatal. Tal argumento, ao qual Petty recorre em Political arithmetick (1690), também encontrou formulação clara no Treatise:

Fewness of people, is real poverty; and a Nation wherein are Eight Millions of people, are more than twice as rich as the same scope of Land wherein are but Four; For the same Governours which are the great charge, may serve near as well, for the greater, as the lesser number (Petty, 1662, p. 35).

Também em matéria de tributação, Petty enfatizava a necessidade de um conhecimento profundo acerca das ocupações dos súditos, sem o qual um sistema 
tributário eficiente não poderia ser construído. Assim, ele explica em Political Arithmetick:

Wherefore upon the whole matter, to know whether a Tax will do good or harm: The State of the People, and their employments, must be well known; (that is to say,) what part of the People are unfit for Labour by their Infancy or Impotency; and also what part are exempt from the same, by reason of their Wealth, Function, or Dignities; or by reason of their charge and employments; otherwise than in governing, directing and preserving those, who are appointed to Labour and Arts (Petty, 1690, p. 258).

O ápice da obsessão de Petty com a administração pública da população encontra-se em suas freqüentes e notáveis tentativas de mensuração do "valor" dos cidadãos. Em Verbum Sapienti (1665), em um capítulo intitulado sugestivamente "On the value of the population", Petty afirma que, como o retorno anual sobre o capital nacional da Inglaterra totalizava 15 milhões de libras, ao passo que a despesa anual global chegava a 40 milhões de libras, as 25 milhões de libras restantes deveriam necessariamente ser atribuídas aos trabalhadores. Depois de uma série de cálculos baseados em estatísticas demográficas e estimativas do valor do estoque nacional de capital, conclui que o valor individual de cada trabalhador para a riqueza do reino seria de 138 libras (1665, p. 103). Vinte e cinco anos mais tarde, de forma mais confiante, Petty proporia raciocínio semelhante em Political Arithmetick, atestando sua perene confiança na relevância social e política do tema:

I shall here digress to set down the way of computing the value of every Head one with another, and that by the instance of People in England, viz. Suppose the People of England be Six Millions in number, that their expence at 7 l. per Head be forty two Millions: suppose also that the Rent of the Lands be eight Millions, and the profit of all the Personal Estate be Eight Millions more; it must needs follow, that the Labour of the People must have supplyed the remaining Twenty Six Millions, the which multiplied by Twenty (the Mass of Mankind being worth Twenty Years purchase as well as Land) makes Five Hundred and Twenty Millions, as the value of the whole People: which number divided by Six Millions, makes above 80 l. Sterling, to be valued of each Head of Man, Woman, and Child, and of adult Persons twice as much; from whence we may learn to compute the loss we have sustained by the Plague, by the Slaughter of Men in War, and by the sending them abroad into the Service of Foreign Princes (Petty, 1690, p. 254-245).

Uma das características marcantes do Essay de Davenant é o uso intensivo de estatísticas acerca de diversos tópicos, espalhadas ao longo do livro na forma de tabelas, ou, como ele prefere chamá-las, "schemes". O tratado de Davenant contempla três temas principais, cada um deles devidamente ilustrado com "esquemas": trabalho, terra e tributação. De forma sugestiva, o primeiro tema abordado é o trabalho, em seção intitulada "Of the people of England". Os esquemas nesta seção apresentam estatísticas demográficas diversas, a começar 
pelo número de pessoas habitando a Inglaterra. É interessante notar que Davenant e King não se satisfazem estimando apenas a população da Inglaterra de então; oferecem também projeções que vão desde 1300 até 2300, fato que certamente indica seu interesse por dinâmicas populacionais. Os esquemas subseqüentes contêm taxas de mortalidade e fertilidade, distribuição etária, assim como rendimentos e despesas domésticas. Tais informações são compiladas separadamente de acordo com gênero, idade, estado civil e, no caso de informações domiciliares, estrato social e ocupação (1699, p. 213-225).

A lógica por trás deste exame minucioso de informações demográficas já foi exposta em uma passagem transcrita acima, "the people being the first matter of power and wealth". Mas o que distingue sua análise é como ele trata a população como uma entidade agregada que deve ser posta a serviço dos interesses nacionais. Para tanto, é necessário adquirir conhecimento completo e detalhado de suas características:

That Gold and Silver are indeed the Measure of Trade, but that the Spring and Original of it, in all Nations, is the Natural or Artificial Product of the Country; [...] There is no Man that can reasonably dispute this Position; and if granted, it follows from thence, That to know rightly how the Balance of Trade stands with any Nation, a due Inspecton must be made into their Natural or Artificial Product. But this Natural or Artificial Product being most of it the Result of the Peoples Labour and Industry, we shall be still in the dark as to all Inquiries of this kind, without maturely considering the Numbers of the People. In these sort of Speculations not only the Quantity but Quality of the Inhabitants must be duly ponder'd, they must be divided into their several Ranks and Classes: It must be distinguish'd who by their Arts, Labour or Industry are increasing, and who by their Expence, Poverty, or Sloth, are decreasing the Kingdom's Wealth. Of these Sub-divisions are likewise to be made, of what Numbers are employed in the Church, in War, in the Fleets Mercantile and Warlike, in the Law, in Offices, in Merchandize, in Shop keeping and Trades, in Handicrafts; and who both of the higher and lower Degree are Persons living upon their Estates; who are Freeholders, Farmers, Labouring People, Servants, Cottagers, Alms-People, and Vagrants (Davenant, 1699, p. 212213).

Davenant acredita que liberdades civis e direitos de propriedade devem ser rigorosamente respeitados, posto que constituem meio extremamente eficaz para aumentar o número de habitantes em uma república (p. 226-227). Seguindo King, traçou uma distinção cuidadosa entre as classes ocupacionais que aumentam a riqueza nacional - onde agrupou nobres, mercadores, fazendeiros, profissionais liberais e advogados, entre outros - e aquelas que a reduzem, por dependerem de transferências de renda de terceiros para sua sobrevivência - categoria que inclui marinheiros, soldados, camponeses e as massas pobres. Tendo estabelecido essa distinção, proporia então medidas para empregar o maior número possível de pessoas em ocupações produtivas, criadoras de riqueza (p. 234-240). Confiante 
como estava nos efeitos indutores de prosperidade advindos de uma vasta população, Davenant sugeriu diversas medidas para estimular o casamento em idade precoce e aumentar as taxas de fertilidade. Como exemplo final de sua perspectiva notavelmente abrangente acerca do papel a ser desempenhado pelo controle estatal sobre a população, a seguinte passagem é esclarecedora:

In order to have Hands to carry on Labour and Manufactures, which must make us Gainers in the Ballance of Trade, we ought not to deterr bur rather invite Men to marry, which is to be done by Priviledges and Exemptions, for such a Number of Children, and by denying certain Offices of Trust and Dignities to all unmarried Persons; and where 'tis once made a Fashion among those of the better Sort, 'twill quickly obtain with the lower Degree (Davenant, 1699, p. 230).

\section{Comentários finais}

Ao longo deste artigo, identificamos uma série de maneiras por meio das quais o tema da população pontuou o pensamento econômico britânico do século XVII. Seja sob a forma de exortações morais a uma conduta laboriosa e frugal, apelos utilitaristas à exploração plena do potencial do trabalho humano para criação de riqueza ou demandas escrupulosas pela integração econômica e social dos pobres, a gerência das massas aparece como um dos temas centrais do período, constantemente abordado pelos pioneiros economistas britânicos. Conforme vimos, os tratamentos mais sistemáticos foram oferecidos por William Petty e Charles Davenant, dois autores completamente desprovidos de restrições quando se tratava de advogar a gerência demográfica estatal.

À luz de tudo o que precede, a emergência da nova "ciência do governo" parece ter ocorrido muito mais cedo do que supunha Foucault. Mais do que isso, conforme as duas epígrafes ao começo do artigo sugerem, os autores do século XVII pareciam estar conscientes do grau de novidade teórica e prática de suas idéias, assim como daquilo a que se opunham. Conforme a lógica econômica e a estatística social desenvolviam-se rapidamente durante o século que precedeu Adam Smith, também ganhava terreno a noção moderna de poder político que concebia a população como seu principal objeto e propósito.

\section{Referências bibliográficas}

BARBON, Nicholas (1696). A discourse concerning coining the new money lighter, In: MAGNUSSON, Lars (Ed.). Mercantilism: critical concepts in the history of economics. London; New York: Routledge, 1995. v. 3, p. 154-206.

CHILD, Josiah (1693). A new discourse of trade, In: MAGNUSSON, Lars (Ed.) Mercantilism: critical concepts in the history of economics. London; New York: Routledge, 1995 . v. 3, p. 1-136.

DAVENANT, Charles (1699). An essay upon the probable methods of making a people gainers in the balance of trade. In: MAGNUSSON, Lars (Ed.) Mercantilism: critical 
Carlos E. Suprinyak

concepts in the history of economics. London; New York: Routledge, 1995, vol. 3, p. 207365 .

FOUCAULT, Michel (1978). Governmentality. In: BURCHELL, Graham et al. (Ed.). The Foucault effect: studies in governmentality. Chicago, IL: University of Chicago Press, 1991, p. 87-104.

JOHNSON, E. A. J. (1937). Predecessors of Adam Smith: the growth of British economic thought. New York: Augustus M. Kelley Publishers, 1965.

LOCKE, John (1691). Some considerations of the consequences of the lowering of interest, and raising the value of money. In: MAGNUSSON, Lars (Ed.). Mercantilism: critical concepts in the history of economics. London; New York: Routledge, 1995. v. 2, p. 55-150.

MAGNUSSON, Lars. Mercantilism: the shaping of an economic language. London; New York: Routledge, 1995.

MALYNES, Gerard (1601). A treatise of the canker of England's common wealth. London.

MISSELDEN, Edward (1622). Free trade or the meanes to make trade flourish. London.

London.

(1623). The circle of commerce or the balance of trade, in defence of free trade.

MUN, Thomas (1621). A discourse of trade from England unto the East Indies. London.

(1664). England's treasure by forraign trade. London. Reprinted: Oxford: Basil Blackweel, 1928.

PETTY, William (1662). A treatise of taxes and contributions. In: HULL, Charles Henry. The economic writings of Sir William Petty. New York: Augustus M. Kelley, 1963, p. 197.

(1665). Verbum sapient. In: HULL, Charles Henry. The economic writings of Sir William Petty. New York: Augustus M. Kelley, 1963, p. 99-120.

(1690). Political arithmetic. In: HULL, Charles Henry. The economic writings of Sir William Petty. New York: Augustus M. Kelley, 1963, p. 233-313. 